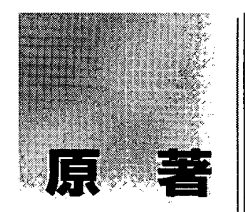

X線CTにおけるX線管回転速度の高速化が画質に与える影響
2003年 3 䛸文受付

論文受理

2003年9月2日

Code Nos. 251

\author{
山口 功1) ·森本 章
}

緒 言

$\mathrm{X}$ 線コンピュー夕断層撮影装置 $(\mathrm{X}$-rays computed tomography：CT)は，基本的にX線管が一回転する間 に取得した投影データより画像を再構成する。そし て, その投影データは, 検出器のチャンネル数, ray 数，view数によって規定され，通常の検査では，ほほ 一定の投影デー夕収集が行われる1,2)。しかし，特殊 な条件下では変化することがあり，view数が減少する ことは画質に直接，影響を与えることになる．その特 殊な条件としてX線管が撮影のために一回転するのに 要する時間(以下，rotation speed）が高速になることが 挙げられる。このrotation speedの高速化は，デー夕収 集装置 (data acquisition system：DAS)のスイッチング 性能や検出器素子のアフターグローなどの影響によっ てview数の減少を生じさせることが予測される。そし て, 空間分解能の低下とあわせて形状再現性の劣化を 引き起こす要因ともなり得る.

原らは, rotation speedが面内空間分解能に影響を与

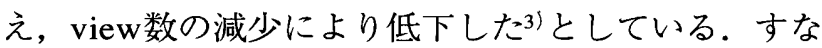
わち, 高速スキャンが多用される近年のCT装置, 特 にmulti-detector row CT (以下，MDCT)では，X線管 回転速度の高速化による画質への影響を検討しておく 必要がある。

今回, rotation speed $1.0 \sim 0.5$ 秒 1 回転(以下, sec/rot) の間で 0.1 秒ごとに可変可能な装置を使用する機会を得 たので，その特性を認識することを目的に, rotation speedの変化が画質に与える影響について物理的評価か ら検討した。そとし，臨床目的としての有効性㧍よび

\title{
Influence of Rotation Speed of X-ray Computed Tomography on Image Quality
} ISAO YAMAGUCHI, ") and AKIRA MORIMOTO

Department of Radiology, Kure Kyosai Hospital

1) Current address:University of Fukui Hospital Radiological Center

Received March 10, 2003; Revision accepted Sept. 2, 2003; Code Nos. 251, 522

\section{Stmmary}

The rotation speed of X-ray CT is known to influence the quality of images. We examined changes in imaging characteristics according to various physical characteristics. The physical characteristic of rotation speed $(1.0,0.8,0.7,0.6,0.5 \mathrm{sec} / \mathrm{rot}$ ) was evaluated at the FOV center(isocenter) and $90 \mathrm{~mm}$ outside the center (off-center). The items of evaluation included low contrast resolution, high contrast resolution, noise, definition, and artifacts. High contrast resolution and definition declined at a rotation speed of 0.6 sec/rot or less at off-center. An increase in shower artifact and change in the shape of the wire section were found at a rotation speed of $0.6 \mathrm{sec} / \mathrm{rot}$ or less at off-center. It was determined that image quality was especially influenced in terms of definition characteristics when the speed of rotation was high. A decrease in the number of views can be considered the main cause; that is, the use of high-speed rotation degrades image quality. Therefore, it is important to consider proper usage as it corresponds with purpose.

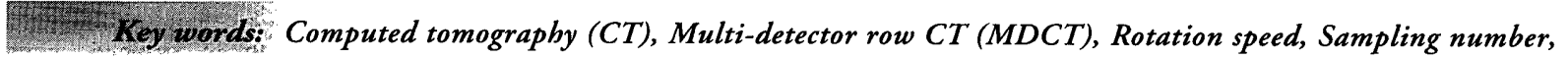
Modulation transfer function (MTF)

別刷資料請求先：テ910-1193 福井県吉田郡松岡町下合月23-3

福井大学医学部附属病院 放射線部 山口 功宛 
注意点について考察した。また，X-Y面内のスキャン 位置による画質特性についても若干の考察を加えた。

\section{1. 方 法}

\section{1-1 使用装置}

CT装置はLightSpeed Plus (GEメディカルシステム株 式会社製4DAS MDCT) を使用した。評価ファントム には，京都科学株式会社製X線コンピュータ断層撮影 装置用ファントム JIS Z4923(以下，JISファントム)を 使用した.

\section{1-2＼cjkstart評価項目および評価方法}

rotation speedのちがいによる低コントラスト分解 能, 高コントラスト分解能, ノイズ特性, 解像度特 性，アーチファクトの 5 項目について以下の方法で測 定した。使用したrotation speedは，1.0，0.8，0.7， $0.6,0.5 \mathrm{sec} / \mathrm{rot}$ である.

X-Y面内の評価位置は，スキャン有効視野 (field of view：FOV)の中心部付近（以下，isocenter）と肺野外 側近傍を想定したFOV中心から $90 \mathrm{~mm}$ 外側 (以下， offcenter)で実施した。

撮影条件は， $120 \mathrm{kVp}$ ，スライス厚 $5 \mathrm{~mm}$ ，スキャン FOV 50cmとし，ソンヘリカルスキャンで評価した. なお， offcenterでの評価はX線が発生されるスタート 位置によって変化することが証明4)されており，厳密 には同期スキャンにて行うことが理想である：しか し，臨床にできるだけ近い状態での検討を目的として いるため10回程度のスキャンから得られる平均値によ つてバラツキを最小限におさえて評価を行った。

\section{1-2-1 低コントラスト分解能}

JISファントム低コントラスト分解能測定部を $220 \mathrm{mAs}$ で10回スキャンし，白石らの提唱する方法5) を用いてROC曲線下の面積を算出して評価した。 な お,この值は, 本来, 密度分解能を評価するものであ るが，第二次勧告の視覚評価と高い相関を示す5)た め，これを低コントラスト分解能の評価值とした．再 構成関数は，標準関数.(STANDARD).を使用した。

\section{1-2-2 高コントラネト分解能}

JISファントム高コントラスト分解能測定部を $100 \mathrm{mAs}$ で10回スキャンし，診療放射線技師 3 名 (経験 年数7〜17年, 平均13.0土4.0)によって視覚的に最小認 識径を評価した6). そのときの表示条件は，表示FOV $15 \mathrm{~cm}$, マトリタスサイズ $512 \times 512$ とし，モニ夕上で window width 300, window level 30に調整して評価を 行った. 再構成関数は, 標準関数を使用した.

\section{1-2-3 ノイズ特性}

JISファントム雑音測定部を蒸留水で充満させ, $100 \mathrm{mAs}$ の条件で10回スキャンし, 表示FOV $25 \mathrm{~cm}$,
マトリクスサイズ512×512におけるディジタルウィナ ースペクトル (Digital Wiener spectra：WS) を算出し た. 再構成関数は，標準関数を使用した. なお，仮想 スリットの幅は40ピクセル，セグメント長は256ピク セル，セグメント数は25ピクセルである. そして，才

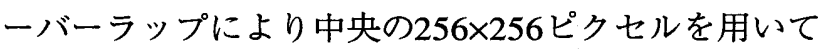
算出した. また，トレンド除去は40ピクセルの移動平 均によるハイパスフィルタリングを用いている。

\section{1-2-4 解像度特性}

JISファントムワイヤ部を空気で満たした状態とし て，100mAsの条件で10回のスキャンを行った。そし て，表示FOV $10 \mathrm{~cm}$, マトリクスサイズ $512 \times 512 に お$ ける線像強度分布を求め, フーリエ変換によって変調 伝達関数 (modulation transfer function : MTF) を算出 した ${ }^{6)}$. 再構成関数は，標準関数と高周波数強調関数 （BONE）を使用した。なお，WS，-MTFの算出には名 古屋市立大学病院放射線部の市川勝弘氏が作成したフ リーソフト (http://home.owari.ne.jp/〜kitikawa/) を使用 した.

1-2-5 アーチファクト

JISファントムワイヤ部を蒸留水で充満させ, $100 \mathrm{mAs}$ 条件で10回スキャンし，得られた画像を診

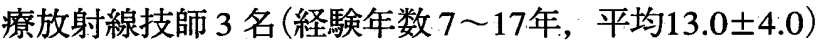
の視覚的観察によってアーチファクトの発生量とワイ ヤ部の形状を比較した，再構成関数は，標準関数を使 用した。

\section{1-3 統計学的解析}

結果のデータは, 削除平均值で表示し，グループ間 の平均值の差は, 両側Paired-t検定によって検定し た。また，統計学的有意差の検定基準は $5 \%$ の危険率 で行った.

\section{2. 結 果}

\section{2-1 低コントラスト分解能}

Fig. 1にファントム画像を，また，Fig. 2にrotation speedをパラメータとしたROC曲線下の面積を表示し た.

各rotation speedのisocenterでの平均值は, $1.0 \mathrm{sec} / \mathrm{rot}$ で $0.696,0.8 \mathrm{sec} / \mathrm{rot}$ で $0.686,0.7 \mathrm{sec} / \mathrm{rot}$ で 0.683 , $0.6 \mathrm{sec} / \mathrm{rot}$ で $0.689,0.5 \mathrm{sec} / \operatorname{rot}$ で 0.694 であった。 ま た, offcenterでは，それぞれ，0.660，0.646，0.645， 0.648, 0.652であり, rotation speed間での有意差は認 めなかった $(\mathrm{p}>0.1)$.

\section{2-2．高コントラスト分解能}

Fig.3にファントム画像を，また，Tableに各rotation speedでの平均最小認識径を表示した。 isocenterでは, 


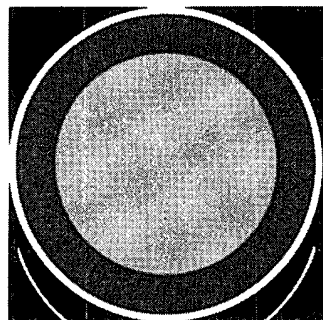

$1.0 \mathrm{sec} / \mathrm{rot}$
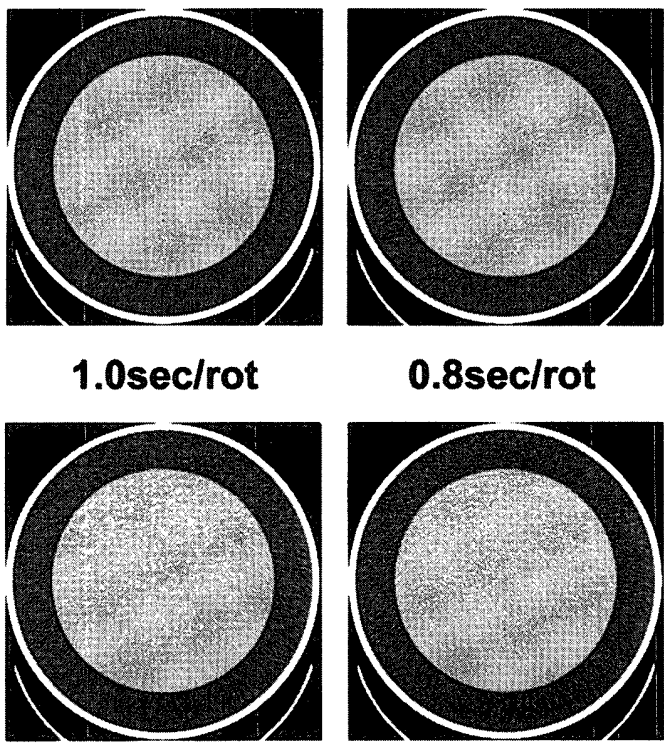

$0.8 \mathrm{sec} / \mathrm{rot}$
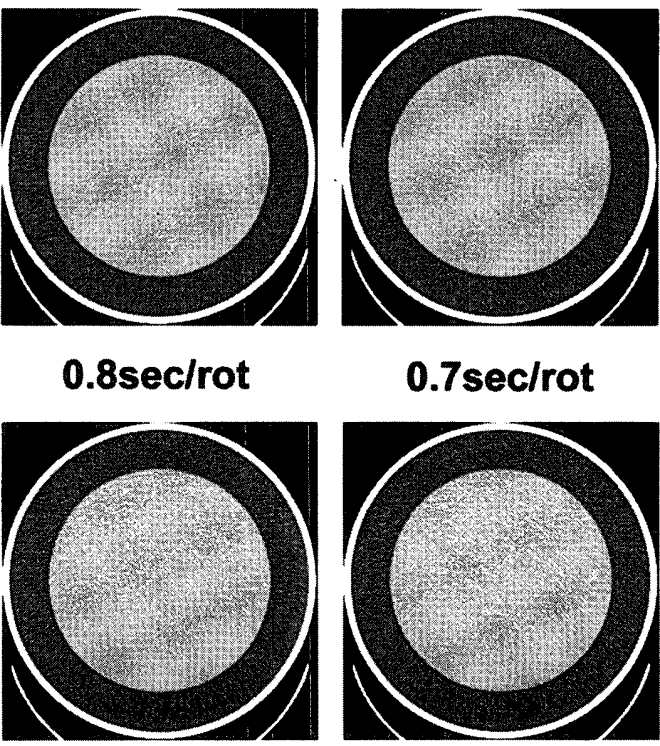

$0.7 \mathrm{sec} / \mathrm{rot}$

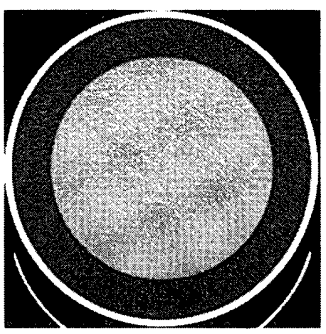

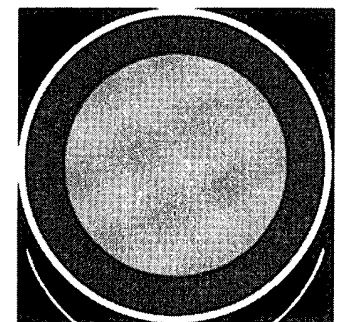

$0.6 \mathrm{sec} / \mathrm{rot}$

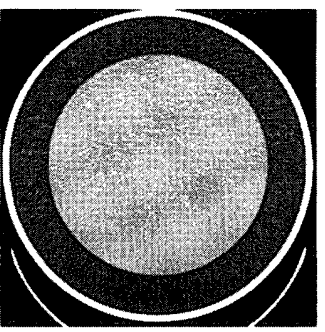

$0.5 \mathrm{sec} / \mathrm{rot}$

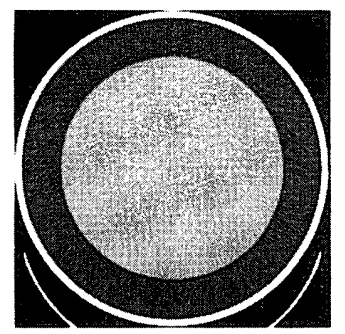

Fig. 1 JIS Phantom image for each rotation speed (low contrast resolution). Upper: isocenter, Lower: off-center.

$120 \mathrm{kVp}, 220 \mathrm{mAs}$, SFOV $50 \mathrm{~cm}$, DFOV $25 \mathrm{~cm}$, STANDARD

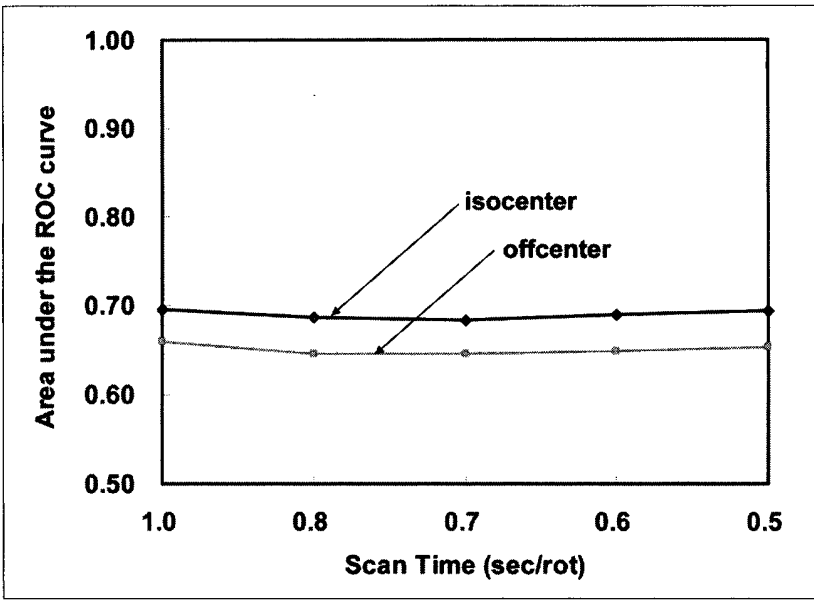

Fig. 2 Comparison of area under the ROC curve for each rotation speed.

There are no significant differences between rotation speeds.

$120 \mathrm{kVp}, 220 \mathrm{mAs}$, SFOV $50 \mathrm{~cm}$, DFOV $25 \mathrm{~cm}$, STANDARD

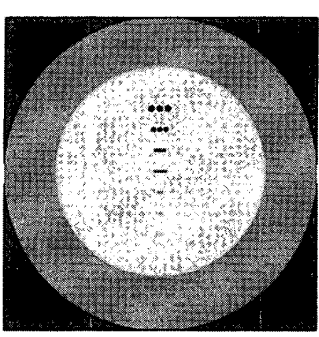

1.0sec/rot

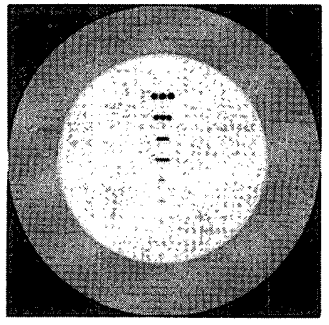

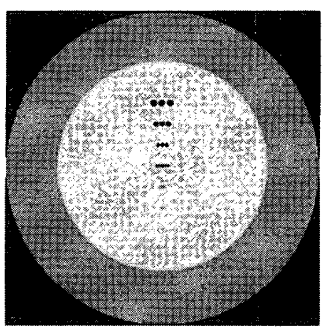

$0.8 \mathrm{sec} / \mathrm{rot}$

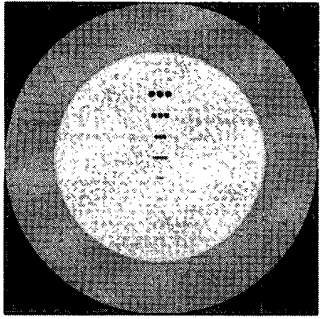

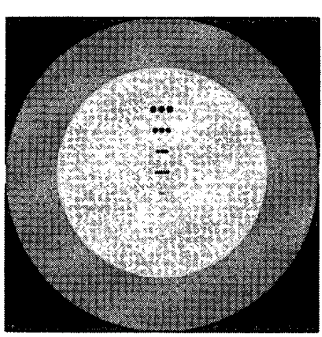

$0.7 \mathrm{sec} / \mathrm{rot}$

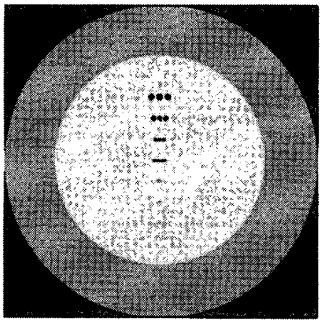

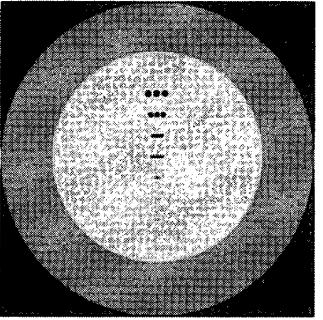

$0.6 \mathrm{sec} / \mathrm{rot}$

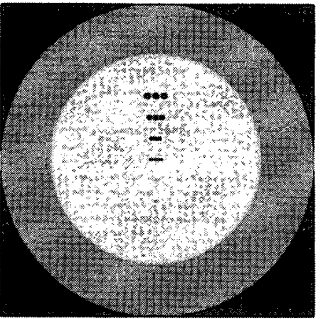

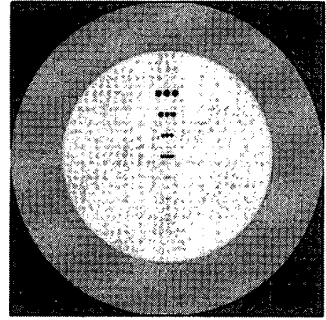

$0.5 \mathrm{sec} / \mathrm{rot}$

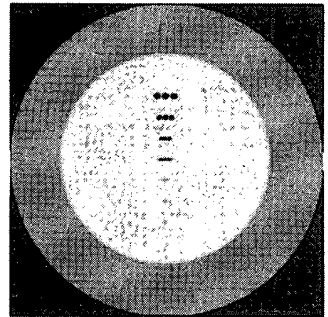

Fig. 3 JIS phantom image for each rotation speed (high contrast resolution). Upper: isocenter, Lower: off-center.

$120 \mathrm{kVp}, 100 \mathrm{mAs}$, SFOV $50 \mathrm{~cm}$, DFOV $15 \mathrm{~cm}$, STANDARD 
Table Sight evaluation of high contrast resolution.

There are no significant differences between isocenters. The minimum diameter for recognition increases by $0.6 \mathrm{sec} /$ rotation or less at off-center. $120 \mathrm{kVp}, 100 \mathrm{mAs}$, SFOV $50 \mathrm{~cm}$, DFOV $15 \mathrm{~cm}$, STANDARD

\begin{tabular}{ccc}
\hline \hline \multirow{2}{*}{ rotation speed } & \multicolumn{2}{c}{ 最小認識径 } \\
\cline { 2 - 3 } & isocenter & offcenter \\
\hline $1.0 \mathrm{sec} /$ rot & $0.7 \mathrm{~mm} \Phi$ & $0.8 \mathrm{~mm} \Phi$ \\
$0.8 \mathrm{sec} / \mathrm{rot}$ & $0.7 \mathrm{~mm} \Phi$ & $0.7 \mathrm{~mm} \Phi$ \\
$0.7 \mathrm{sec} / \mathrm{rot}$ & $0.7 \mathrm{~mm} \Phi$ & $0.7 \mathrm{~mm} \Phi$ \\
$0.6 \mathrm{sec} / \mathrm{rot}$ & $0.7 \mathrm{~mm} \Phi$ & $1.0 \mathrm{~mm} \Phi$ \\
$0.5 \mathrm{sec} / \mathrm{rot}$ & $0.7 \mathrm{~mm} \Phi$ & $1.0 \mathrm{~mm} \Phi$ \\
\hline
\end{tabular}
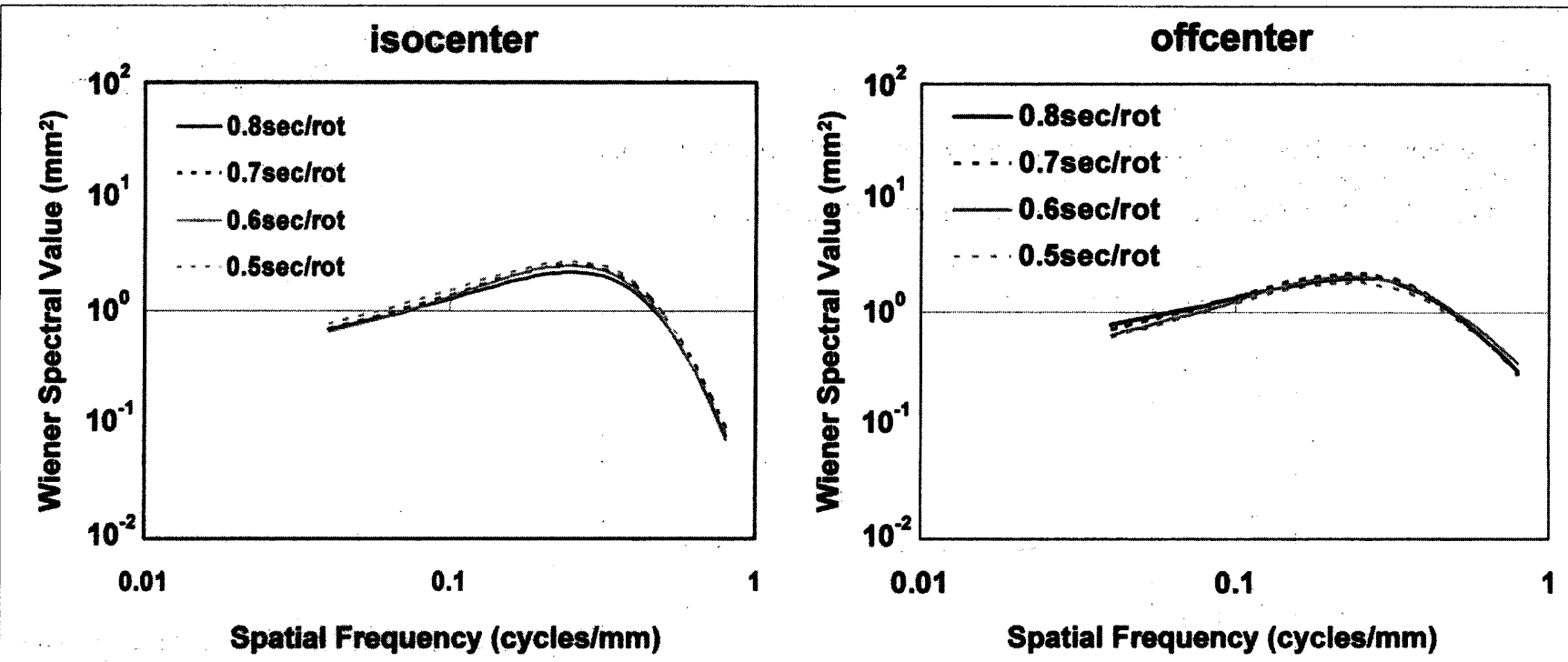

Fig. 4 Comparison of digital Wiener spectra according to scan time. There are no significant differences between rotation speeds. $120 \mathrm{kVp}, 100 \mathrm{mAs}$, SFOV $50 \mathrm{~cm}$, DFOV $15 \mathrm{~cm}$, STANDARD

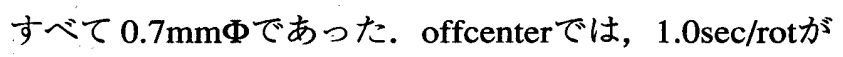
$0.8 \mathrm{~mm} \Phi, 0.8$ および $0.7 \mathrm{sec} / \operatorname{rot}$ が $0.7 \mathrm{~mm} \Phi ， 0.6$ おび $0.5 \mathrm{sec} / \mathrm{rot}$ が $1.0 \mathrm{~mm} \Phi$ あったた.

\section{2-3ノイズ特性}

Fig. 4にrotation speed $0.8 \sim 0.5 \mathrm{sec} / \operatorname{rot} の W S$ 表示し た. isocenter, offcenterともにrotation speedのちがいに

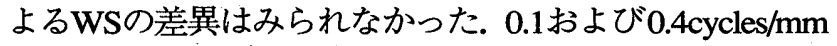
の周波数における比較では, isocenter, offcenterともに WS值に有意差は認められなかった $(\mathrm{p}>0.05)$.

\section{2-4 解像度特性}

Fig. 5に標準関数，また, Fig. 6に高周波数強調関数 におけるrotation speed $0.8 〜 0.5 \mathrm{sec} / \mathrm{rot}$ のMTFを表示し た. 両再構成関数とも isocenterでは，ほほ同等であっ たが, offcenterにおいて, rotation speed 0.6および $0.5 \mathrm{sec} / \mathrm{rot}$ でMTFの低下がみられた。MTF 10\%におけ
る周波数解像度の比較では, 両関数ともisocenterで は，有意差は認められなかった $(\mathrm{p}>0.05)$. しかし，off centerでは，0.6および $0.5 \mathrm{sec} / \mathrm{rot}$ で有意な低下を認め た $(\mathrm{p}<0.001)$.

\section{2-5 アーチファクト}

Fig. 7にisocenterおよびoffcenterそれぞれのファント ム画像を表示した．診療放射線技師 3 名の視覚評価で 一致した回答が得られたため，それを結果とした。 isocenterでは, アーチファクト量, ワイヤの形状に 変化は認められなかった. しかし, offcenterにおいて $0.6 \mathrm{sec} / \mathrm{rot}$ 以下でワイヤから発生するシャワー状のアー

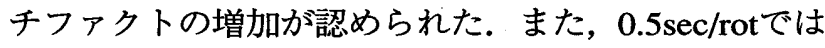
ワイヤ部断面が楕円型に変化する形状再現性の低下を 認めた。 

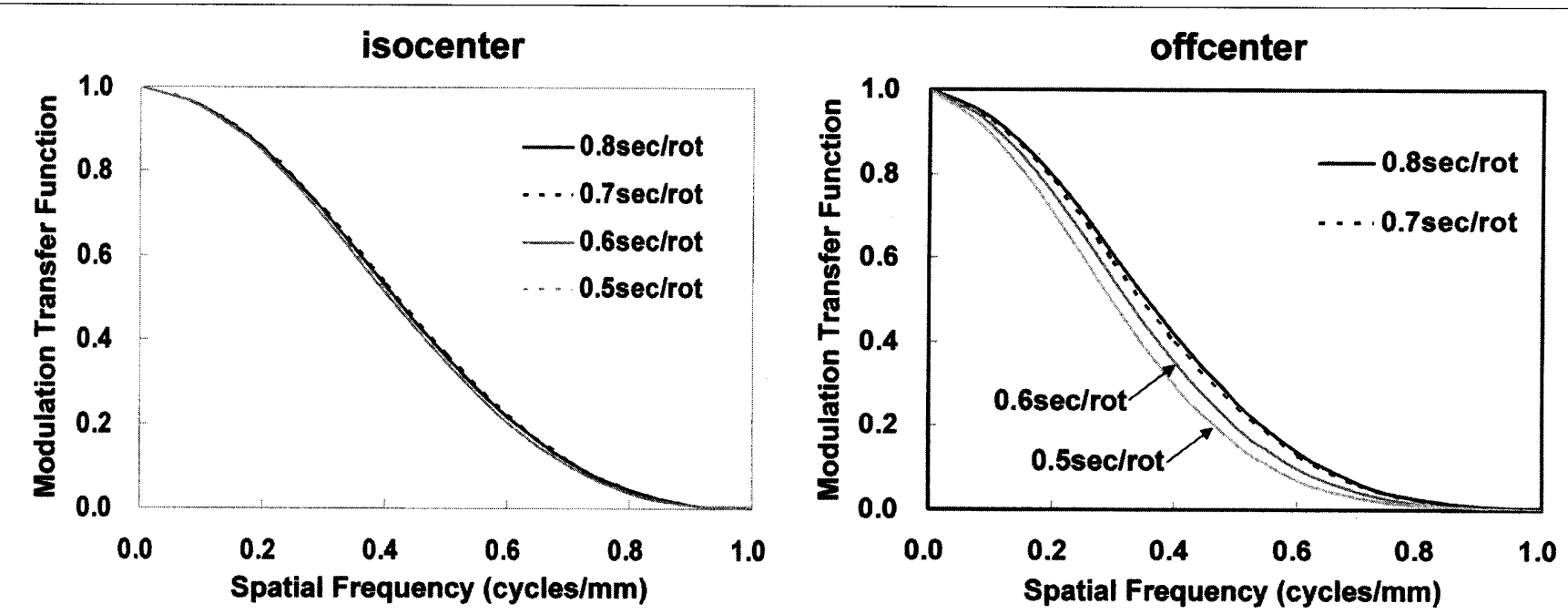

Fig. 5 Comparison of MTF according to rotation speed (STANDARD).

There are no significant differences in isocenter. A decrease in MTF is noted at $0.6 \mathrm{sec} / \mathrm{rot}$ or less at off-center. $120 \mathrm{kVp}, 100 \mathrm{mAs}$, SFOV $50 \mathrm{~cm}$, DFOV $10 \mathrm{~cm}$, STANDARD
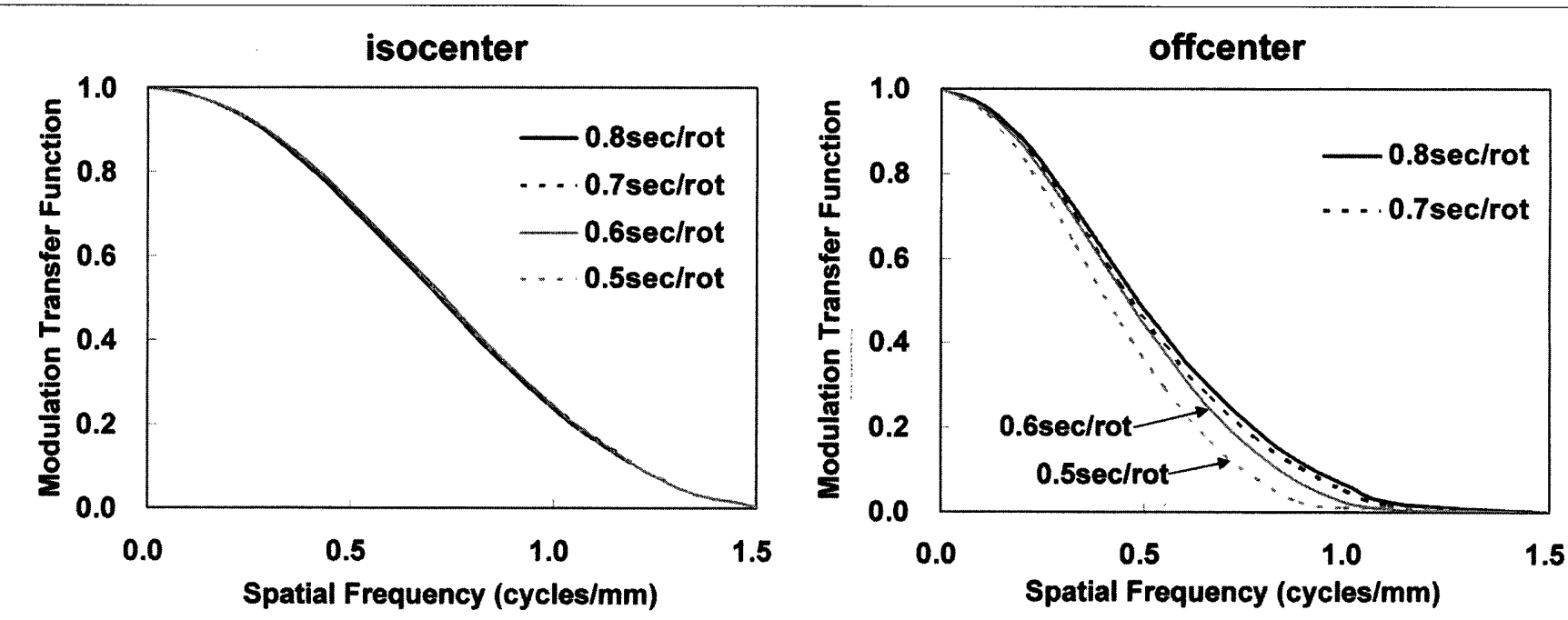

Fig. 6 Comparison of MTF according to rotation speed (BONE).

There are no significant differences between isocenters. A decrease in MTF is noted at 0.6 sec/rot or less at offcenter.

$120 \mathrm{kVp}, 100 \mathrm{mAs}$, SFOV $50 \mathrm{~cm}$, DFOV $10 \mathrm{~cm}$, BONE

\section{3. 考 察}

rotation speedによる物理特性の変化は, 予測されて いたようにアーチファクトを含めた空間分解能に関係 するもので影響がみられた。 そして，その影響は，デ ータが密であるFOVの中心付近では少なく，粗となる FOVの辺縁部で多くみられている.

辺縁ほど空間分解能が低下することは, rotation speedのみの影響ではなく, X-Y面内の位置依存性も 関与していると考えられる。 そのため, rotation speed の影響と面内位置依存性を分離して評価する必要があ る.そのため，1-2-4と同様の方法にて次の実験を追 加した。まず，X-Y面内の位置依存性を知るために,
$0.8 \mathrm{sec} / \mathrm{rot}$ を例にとり，FOVの中心から $20 \mathrm{~mm}$ ごと辺縁 へ離れたときのMTFを測定した。そして，MTF 50\% のときの周波数解像度をcenterの值で正規化し，その 結果をFig. 8に表示した。これよりFOV中心から60mm を超えて離れたところからMTFの低下が確認できる. 次にrotation speedによる影響を知るため, $0.8 \mathrm{sec} / \mathrm{rot} と$ $0.5 \mathrm{sec} / \mathrm{rot}$ を用いて面内位置依存性と同様の方法でMTF を測定した。そして，各距離において， $0.5 \mathrm{sec} / \mathrm{rot} の$ MTF 50\%の周波数解像度をFig. 8で得られた $0.8 \mathrm{sec} / \mathrm{rot}$ のそれで正規化した結果をFig. 9に表示した．FOV中 心から $20 \mathrm{~mm}$ を超えて離れたところから $0.8 \mathrm{sec} / \mathrm{rot}$ $0.5 \mathrm{sec} / \mathrm{rot}$ MTFに差異が生じている. 


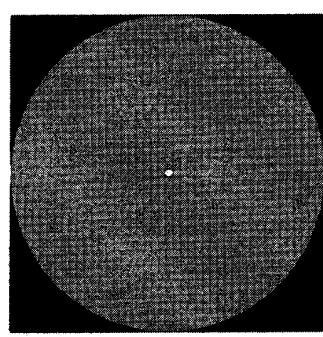

$1.0 \mathrm{sec} / \mathrm{rot}$

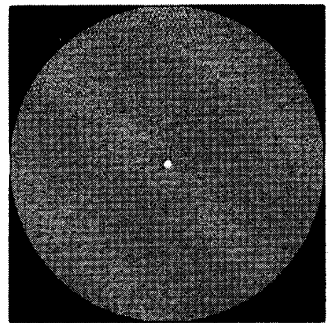

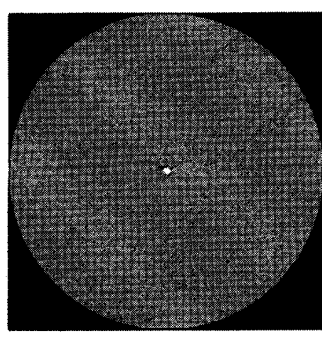

0.8 sec/rot

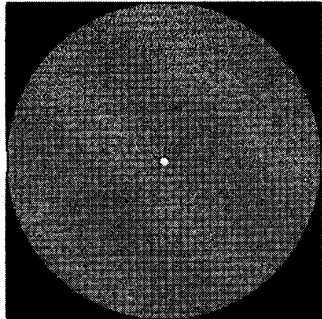

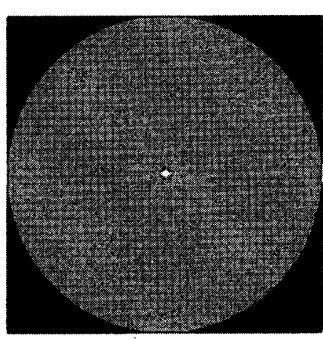

$0.7 \mathrm{sec} / \mathrm{rot}$

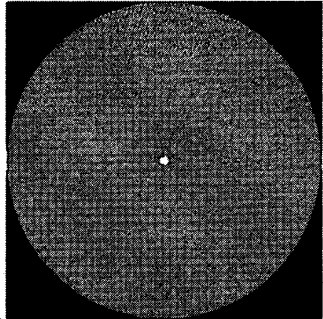

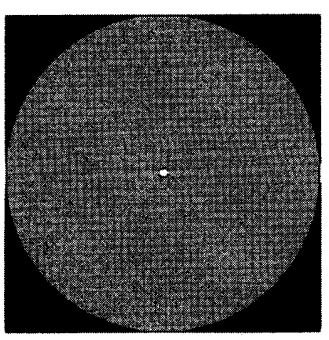

0.6 sec/rot

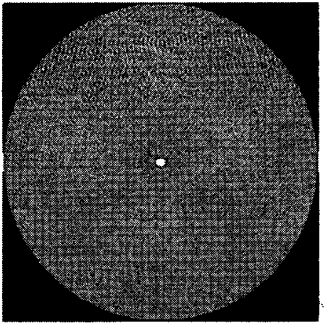

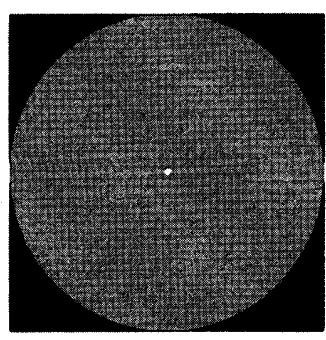

0.5 sec/rot

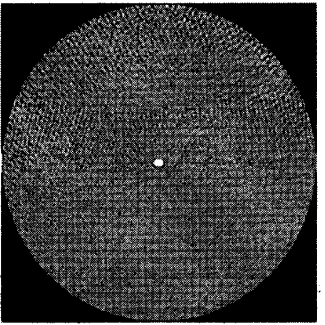

Fig. 7 Comparison of artifacts according to rotation speed.

Artifacts increased at less than $0.6 \mathrm{sec} / \mathrm{rot}$ at off-center. The change in shape of the wire section takes place at 0.5 sec/rot.

Upper: isocenter, Lower: off-center.

$120 \mathrm{kVp}, 100 \mathrm{mAs}$, SFOV $50 \mathrm{~cm}$, DFOV $10 \mathrm{~cm}$, STANDARD

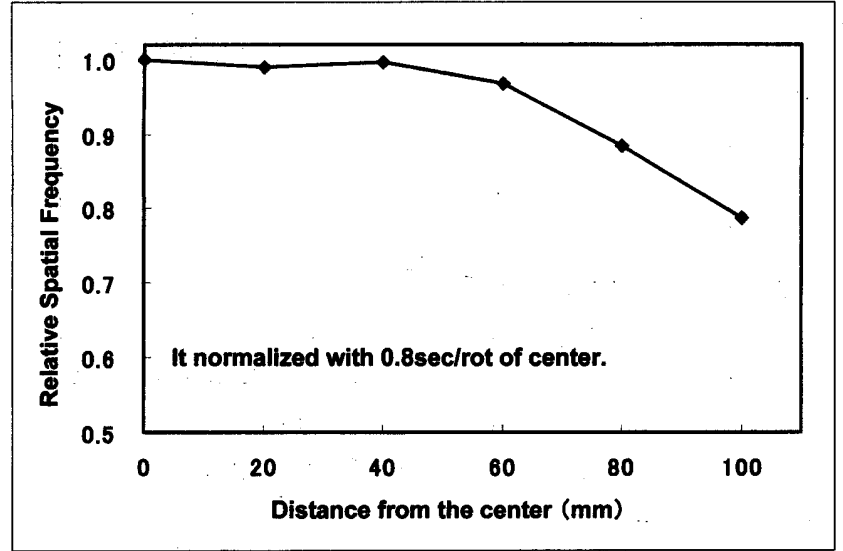

Fig. 8 Change in MTF according to position in the $X-Y$ plane.

Comparison according to distance from the FOV center at rotation speed $0.8 \mathrm{sec} / \mathrm{rot}$. (Relative comparison with the center of FOV.)

The decrease in MTF occurs at distances beyond $60 \mathrm{~mm}$ from the center.

$120 \mathrm{kVp}, 100 \mathrm{mAs}$, SFOV $50 \mathrm{~cm}$, DFOV $10 \mathrm{~cm}$, STANDARD

以上, 二つの結果からrotation speed と面内位置依存 性を分離して評価することができ， rotation speedによ って空間分解能に差異が発生するのはFOV中心から 20mmを超えて離れた位置からであり，60mmを超え て離れると面内位置依存性もプラスされ，空間分解能 の劣化が加速するといえる. しかし， rotation speed間 の差異は，面内位置依存性と相殺され，拡大すること は少ないともいえる.

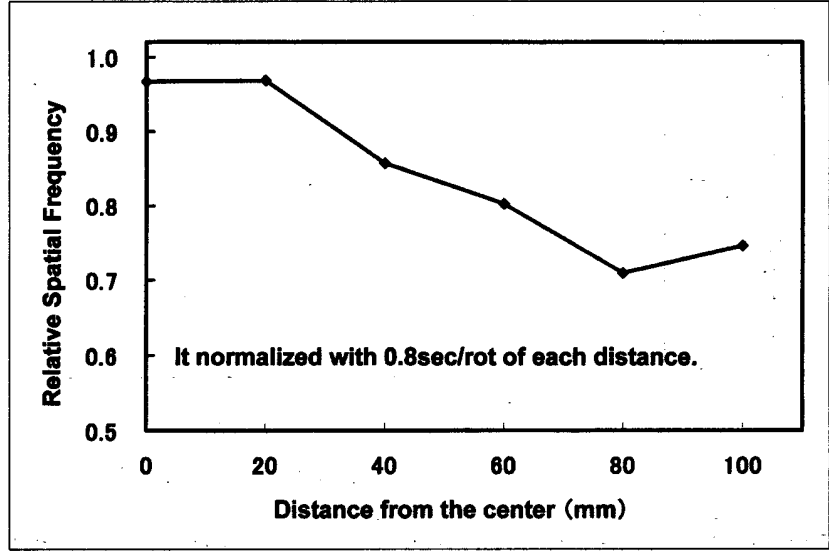

Fig. 9 Change in MTF according to position in the $X-Y$ plane.

Comparison between rotation speeds of $0.8 \mathrm{sec} / \mathrm{rot}$ and $0.5 \mathrm{sec} / \mathrm{rot}$ according to distance from the FOV center (comparison of the relative difference for each distance).

There is a difference in scan time because the distance is more than $20 \mathrm{~mm}$ from the center. $120 \mathrm{kVp}, 100 \mathrm{mAs}$, SFOV $50 \mathrm{~cm}$, DFOV $10 \mathrm{~cm}$, STANDARD

低コントラスト分解能では, rotation speedによる画 質への影響はみられなかったが，X-Y面内における FOV辺縁部で低下が認められ, 面内位置依存性の存在 が示唆される。低コントラスト分解能の指標とした ROC曲線下の面積は, offcenterで 6\%程度の有意な低 下が認められる $(\mathrm{p}<0.001)$ 。これは, offcenterのアー チファクトの増加が関与したものと考えられる。 た，高周波数域における雑音がcenterで増大している 
が，これは，この周波数域の解像度特性がoffcenterよ り優位であることとcenterの実効スライス厚がoffcenter より多少，小さいことが反映したものと考える。

rotation speedによって画質が変化した主原因は， view数の減少すなわちサンプリング数の減少によって 再構成される画像にエイリアシングの影響が加わった ためと考えられる。 また，X-Y面内位置では回転中心 から対象物が離れるに伴い，投影角によって投影デー 夕の值が変動したことと検出器に入射する投影データ の拡大率が投影角ごとに異なったことが形状再現性や 空間分解能を劣化させたと考えられる。本装置のview 数は公開されていないが，ユーザーとして知り得た view数として $0.7 \mathrm{sec} / \mathrm{rot}$ 以上は, 約 $980 \mathrm{view} / \mathrm{rot}$ ある のに対して, $0.6 \mathrm{sec} / \mathrm{rot}$ では840view/rot, $0.5 \mathrm{sec} / \mathrm{rot}$ は704view/rotと減少していた。この值は, 公称值とし て得られたものではないが, 高コントラスト分解能の 視覚評価およびMTFによる解像度特性の結果と強い相 関がみられることからview数の低下によって生じた現 象であると結論づけることができる，本装置は，最新

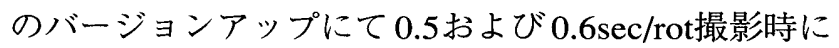
おけるDASサンプリング率を1640view/secに増加する ことが公表7)されているため, 今後, 画質は改善され るものと期待できる.

それでは，これらの現象が臨床目的としてどのよう な影響を与えるだろうか。

最も影響が懸念されるものが肺の高分解能CT (high resolution CT：HRCT) である. HRCTは, 肺腫瘤性病 変の構造把握やびまん性肺疾患に対する肺二次小葉レ ベルの病変分布の詳細な観察を目的に多く用いられる ものであり, 空間分解能が重要な因子となる. 今回評 価したoffcenterは，このHRCTでの肺末梢部にほぼ一 致するが, FOV周辺部における空間分解能低下は避け ることができないため,できる限り rotation speedによ る影響は排除することが望ましい, そのため, 空間分 解能の劣化を生じない $0.7 \mathrm{sec} / \mathrm{rot}$ 以上のrotation speed の選択が必要である。しかし，心蔵近傍ではモーショ ンアーチファクトとトレードオフの関係となり, FOV 内の位置を考慮したうえで $0.5 \mathrm{sec} / \mathrm{rot}$ 使用すべきで ある。また，近年注目されている心蔵領域では，対象 がFOV中心付近にあるため影響を受けることは少ない と考える。そのほか, 造影剤の急速静注によるmulti phase scanが多く実施され，短時間撮影が有効とされる 腹部領域の評価では密度分解能が重要な因子であるた め, rotation speedによる空間分解能の劣化が臨床画像 へ影響することは少ない. したがって，腹部造影CT, 特に, dynamic studyでは時間分解能を優先することが

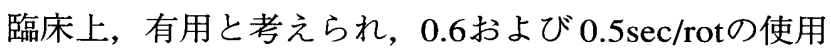
は必要不可欠なものである。 また，短時間撮影により
被検者の呼吸抑制時間の短縮など，利点も生じる. 短時間撮影によってFOV辺縁部でアーチファクトの 増加がみられたが, 臨床においては, 肋骨などの高吸 収体からのアーチファクトが多く発生することが予測 される．特に，ヘリカルスキャン時にhigh pitch(本装 置ではhelical pitch 6.0, IEC表示では1.5) と組み合わ せることでアーチファクトの発生が顕著になることが 臨床上でも認められている8). この現象は, 原らが提 唱したViewデータ密度 (view data density on Z-axis : $\mathrm{VDDz})^{3)}$ の考え方を用いると理解できるものである.

また, FOV辺縁部における形状再現性の劣化は, 体 幹辺縁に存在する構造物を3D表示する場合に影響を 与える可能性が示唆される.これは, 臨床上の確認が されていないため今後, 早急に評価する必要がある.

このように高速スキャンは，臨床上，有用性が高い 反面，画質を劣化させることもある，したがってview 数の減少が画質に与える影響を理解したうえで，画一 的なrotation speedを使用するのではなく，臨床目的と 照らし合わせて適正なrotation speedを選択することが 重要である。そして，このように物理現象を理解した うえで臨床画像に反映させることがわれわれの責務と 考える。

\section{4. 結 語}

高速スキャンが多用される近年のCT装置におい て，X線管回転速度の高速化が画質に与える影響を確 認するためrotation speedとX-Y面内の位置を変化させ 得られた物理評価をもとに検討した。

rotation speedが物理特性に与える影響としては，空間 分解能に関係するもので確認され，FOV辺縁部におけ る $0.6 \mathrm{sec} /$ rot以下のrotation speedで劣化が認められる. また，密度分解能は，X-Y面内上のどの位置においても 影響を受けることは少ない.しかし，密度分解能，空 間分解能ともにX-Y面内での位置依存性が存在し，FOV 中心から離れることで低下することが認められる。

この空間分解能の低下は撮影目的によって臨床画像 に影響を与えることになる，すなわち，高速スキャン による投影デー夕数の減少は, CTの原理上, 避ける ことができないため物理現象を理解したうえで臨床目 的に応じた使い分けをすることが重要である。

\section{謝 辞}

稿を終わるにあたり，解析ソフトの使用を快諾いただ くとともに貴重な助言を賜りました名古屋市立大学病院 放射線部の市川勝弘氏に厚くお礼を申し上げます。

なお, 本研究の要旨は第58回日本放射線技術学会総 合学術大会 (神戸)にて発表した。 


\section{参考文献}

1) 辻岡勝美：CT自由自在. メジカルビュー社, 26-27, 東 京, (2001)。

2) Weiss GH, Talbert AJ, and Brooks RA: The use of phantom view to reduce CT streaks due to insufficient angular sampling. Phys Med Biol, 27(9), 1151-1162,(1982).

3) 原 孝則, 加藤秀記, 秋山充年; 他 : multi-slice CT (MSCT)における面内空間分解能の基礎的検討. 日放技学 誌； 58(4)，473-478，(2002).

4）勝田昭一, 花井耕造, 国井岳夫, 他: ヘリカルCTに扔ける スライス感度プロフィールの撮像領域内位置依存性. 日放 技学誌, 55(11), 1109-1114, (1999).
5) 白石順二, 上田容子, 宇都宮あかね; 他 : ROC解析をCT 装置の密度分解能の測定. 日放技学誌，53(4)，431-436, (1997).

6）日本放射線技術学会 編：臨床放射線技術実験ハンドブック (上)，第 5 章 X線CT検査系. 通商産業研究社，381-464, 東京, (1996).

7) GE横河メディカルシステム 編：カスタマーコールセンタ 一でのFAQ-CT編. GE today, 10, 5-6, (2003).

8) Wang G, and Vannier MW: The effect of pitch in multislice spiral/helical CT. Med Phys, 26 (12), 2648-2653, (1999).

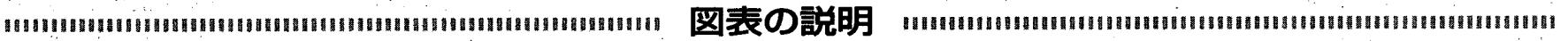

Fig. 1 ; 各rotation speedにおけるJISファントム画像(低コントラスト分解能)

上段：isocenter, 下段：offcenter

$120 \mathrm{kVp}, 220 \mathrm{mAs}$, SFOV $50 \mathrm{~cm}$, DFOV $25 \mathrm{~cm}$, STANDARD

Fig. 2 各rotation speedにおけるROC曲線下の面積の比較

rotation speed間に有意な差は認めない.

$120 \mathrm{kVp}, 220 \mathrm{mAs}$, SFOV $50 \mathrm{~cm}$, DFOV $25 \mathrm{~cm}$, STANDARD

Fig. 3 各rotation speedに掠けるJISファントム画像(高コントラスト分解能)

上段：isocenter, 下段 : offcenter

$120 \mathrm{kVp}, 100 \mathrm{mAs}$, SFOV $50 \mathrm{~cm}$, DFOV $15 \mathrm{~cm}$, STANDARD

Fig. 4 rotation speedのちがいによるディジタルウィナースペクトルの比較

rotation speed間に有意な差は認めない.

$120 \mathrm{kVp}, 100 \mathrm{mAs}$, SFOV $50 \mathrm{~cm}$, DFOV $15 \mathrm{~cm}$, STANDARD

Fig. 5 rotation speedのちがいによるMTFの比較(標準関数)

isocenterでは有意差はみられないが, offcenterの 0.6sec/rot以下でMTFの低下が認められる.

$120 \mathrm{kVp}, 100 \mathrm{mAs}$, SFOV $50 \mathrm{~cm}$, DFOV $10 \mathrm{~cm}$, STANDARD

Fig. 6 rotation speedのちがいによるMTFの比較(高周波数強調関数)

isocenterでは有意差はみられないが, offcenterの 0.6sec/rot以下でMTFの低下が認められる。

$120 \mathrm{kVp}, 100 \mathrm{mAs}$, SFOV $50 \mathrm{~cm}$, DFOV $10 \mathrm{~cm}$, BONE

Fig. 7 rotation speedのちがいによるアーチファクトの比較

offcenterにおいて 0.6sec/rot以下でアーチファクトの増加がみられ，0.5sec/rotでワイヤ断面の形状変化が生じている.

上段：isocenter, 下段：offcenter

$120 \mathrm{kVp}, 100 \mathrm{mAs}$, SFOV $50 \mathrm{~cm}$, DFOV $10 \mathrm{~cm}$, STANDARD

Fig. 8 X-Y面内の位置によるMTFの変化

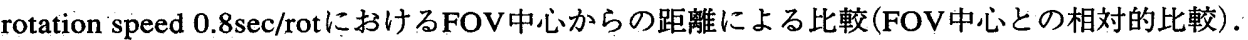

中心から60mmを超えて離れるとMTFの低下が生じている.

$120 \mathrm{kVp}, 100 \mathrm{mAs}$, SFOV $50 \mathrm{~cm}$, DFOV $10 \mathrm{~cm}$, STANDARD

Fig. 9 X-Y面内の位置によるMTFの変化

FOV中心からの距離によるrotation speed $0.8 \mathrm{sec} / \mathrm{rot}$ と0.5 sec/rotの比較 (各距離における相対的差異の比較).

中心から20mmを超えて離れることでrotation speed間に差異が生じている。

$120 \mathrm{kVp}$, 100mAs, SFOV $50 \mathrm{~cm}$, DFOV $10 \mathrm{~cm}$, STANDARD

Table＼cjkstart高コントラスト分解能の視覚評価

isocenterでは有意差はみられないが, offcenterの 0.6sec/rot以下で最小認識径が増大している。

$120 \mathrm{kVp}, 100 \mathrm{mAs}$, SFOV $50 \mathrm{~cm}$, DFOV $15 \mathrm{~cm}$, STANDARD 